\title{
EXPRESSION OF GA COAT PROTEIN-DERIVED MOSAIC VIRUS-LIKE PARTICLES IN Saccharomyces cerevisiae AND PACKAGING in vivo OF mRNAs INTO PARTICLES
}

\author{
Arnis Strods, Dagnija Ārgule, Indulis Cielēns, Ludmila Jackeviča, and Regīna Renhofa
}

Biomedical Research and Study Centre, Rātsupītes ielā 1, Rīgā, LV-1067, LATVIA;

a.strods@biomed.lu.lv

Communicated by Pauls Pumpēns

\begin{abstract}
Our previous research showed that the best yield of virus-like particles (VLPS) formed by RNA bacteriophage GA coat protein was obtained by expression in yeast Pichia pastoris, while other used expression systems in Saccharomyces cerevisiae gave much lower amounts of capsids. The main reasons to attempt further studies in Saccharomyces cerevisiae were to improve the yield of GA-based VLPs using constructs with optimised nucleotide triplets in coding sequences, and to exploit the possibilities of the two-promoter Gal1/Gal10 system of expression vector pESC-URA for production of the desired mosaic VLPS and for packaging of mRNAs into VLPS in vivo.
\end{abstract}

\section{INTRODUCTION}

Yeast expression systems are successfully used for production of heterologous proteins and for generation of viruslike particles (VLPs) of several sources (Strausberg and Strausberg, 2001; Sasnauskas et al., 2002; TsunetsuguYokota et al., 2002; Chen et al., 2004; Juozapaitis et al., 2005; Mach et al., 2006; Freivalds et al, 2011). Our particular interest is the potential of yeast cells as a host for producing properly folded bacteriophage $\mathrm{MS} 2, \mathrm{Q} \beta$ and GA coat protein-derived VLPs (Legendre and Fastrez, 2005; Freivalds et al., 2006; Freivalds et al., 2008; Rūmnieks et al., 2008; Sun et al., 2011), also with simultaneously packaged mRNAs in vivo (Legendre and Fastrez, 2005; Rūmnieks et al., 2008; Sun et al., 2011). Here we continue our previous investigations (Freivalds et al., 2008; Rūmnieks et al., 2008) in several aspects: 1) to improve the yield of VLPs formed by GA coat protein in Saccharomyces cerevisiae by use of optimised, yeast-characteristic codons, 2 ) to produce nanoparticles with in vivo packaged mRNAs coding „,reporter” protein GFP or interleukin-2, 3) to exploit the two-promoter expression system pESC-URA for production of mosaic particles formed from two proteins GA coat protein and this protein fused with the desired eukaryotic sequence, this time with fragment of HIV Tat sequence and with West Nile Virus E protein DIII chain. Such an approach to form mosaic particles often is the only possibility to involve foreign protein sequences into soluble structures and to utilise them in further investigations.

In our previous papers (Freivalds et al., 2008; Rūmnieks et al., 2008), the GA coat protein (CP) encoding gene was amplified from Escherichia coli expression plasmid pGA-355-24. The CP aminoacid sequence encoded by this plasmid is identical to that published by Tars et al., 1997. The coding sequence for this plasmid was obtained by RT of full-length bacteriophage GA RNA, and therefore, it could be designated as original (Escherichia coli specific). Previously it was shown (Freivalds et al., 2008) that the highest yield of GA CP VLPs was obtained in the case of yeast Pichia pastoris. In Saccharomyces cerevisiae, the yield of GA CP-formed particles was lower - up to two times for AH22/pFX-GA and remarkably low for YPH499/ pESCURA. Both Saccharomyces cerevisiae vectors exist in cells as episomes. Our particular interest was vector pESC-URA from Stratagene, which has two regulated promoters Gal1 and Gal10 that are very powerfully induced by galactose (up to 1000-fold). The Gal1 and Gal10 promoters share a common upstream activating sequence, which transcribe in opposite orientations and can be used to express two products simultaneously and in approximately equivalent amounts. To attempt to improve yield of GA CP-derived particles, we decided to switch from original Escherichia coli preferred codons to optimised ones for yeast. It is considered that optimal codons can aid to achieve faster translation rates and higher accuracy of those processes. Optimal codons in fast-growing microorganisms, like Escherichia coli or Saccharomyces cerevisiae, reflect the composition of their respective genomic tRNA pool. Preferred codon usage in $E$. coli and yeast is quite different (Klump and Maeder, 1991). To convert the E. coli original GA CP sequence into an optimal one for yeast, a built-in Saccharomyces cerevisiae codon table from the Invitrogen software package Vector NTI 10 was used. Additional corrections were made by us to eliminate blocks with more than four identical nucleotides. The resulting GA CP coding sequence used in further work is displayed in Figure 1. 


GA CP
GA CP generated
GA CP optimised
aminoacid sequence (1)
GA CP
GA CP generated
GA CP optimised
aminoacid sequence (16)
GA CP
GA CP generated
GA CP optimised
aminoacid sequence (31)
GA CP
GA CP generated
GA CP optimised
aminoacid sequence (46)

\section{GA CP}

GA CP generated

GA CP optimised

aminoacid sequence (61)

GA CP
GA CP generated
GA CP optimised
aminoacid sequence (76)

\section{GA CP}

GA CP generated

GA CP optimised

aminoacid sequence (91)

GA CP

GA CP generated

GA CP optimised

aminoacid sequence (106)

\section{GA CP}

GA CP generated

GA CP optimised

aminoacid sequence (121)
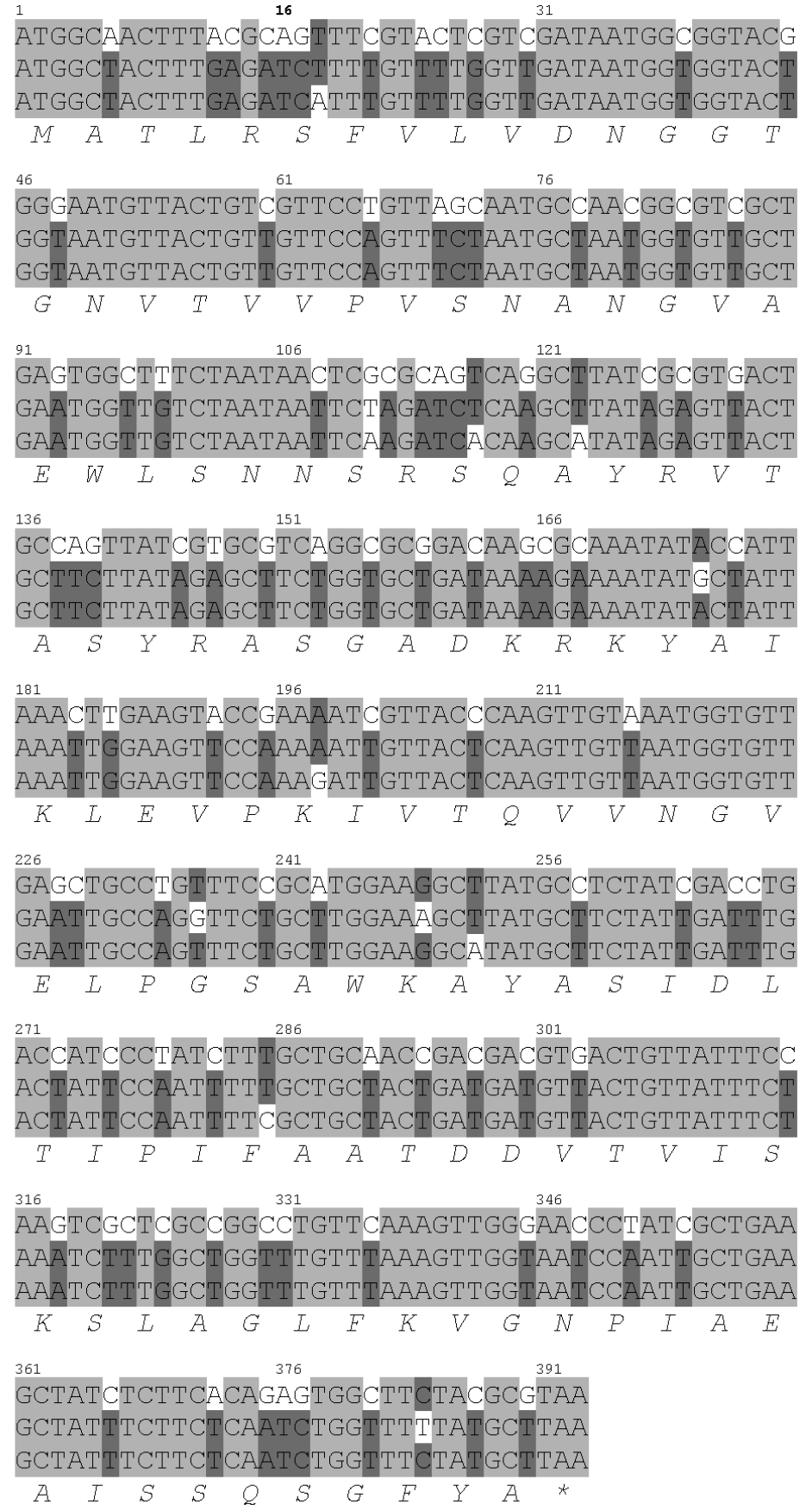

Fig. 1. Comparison of GA CP original, software generated and optimised (manually corrected) codon sequences.

\section{MATERIALS AND METHODS}

Materials. The materials employed were: Anti-Interleukin-2 Antikörper (online-antibodies $\mathrm{GmbH}$ ); Pro-Q ${ }^{\circledR}$ Diamond Phosphoprotein Gel Stain (Molecular Probes, Invitrogen); Shrimp Alkaline Phosphatase (Fermentas); pESC Yeast Epitope Tagging Vectors (Stratagene); plasmid pUC57-GA containing GA coat protein sequence encoded with yeast optimized codons (GeneScript); Yeast Transformation Kit (Sigma) and First Strand cDNA Synthesis Kit (Fermentas).

Plasmids and constructions. All used constructions made by ligation of vectors and appropriate fragments (synthesised in PCR reaction and digested with vector-consistent restriction endonucleases), are summarised in Table 1. Two
S. cerevisiae plasmids with original GA CP gene sequences were already available - pESC-GA was obtained from previous experiments (Freivalds et al., 2008) and pFX-GA was a kind gift from Dr. Andris Kazāks (Freivalds et al., 2008). Constructions with optimised codons were prepared on the basis of those two plasmids:

(1) for expression in yeast AH22, the construction pAS66 was made by cutting the coat protein gene from plasmid pUC57-GA and inserting it in the vector derived from pFX-GA;

(2) for expression in yeast YPH499, constructions pAS65 and pIC971 were synthesised by cloning out the GA CP coding sequence from plasmid pUC57-GA by PCR reaction 
OVERVIEW OF SYNTHESISED PLASMIDS

\begin{tabular}{|c|c|c|c|c|}
\hline \multirow[b]{2}{*}{ Construct } & \multirow[b]{2}{*}{ Input vector } & \multicolumn{3}{|l|}{ Fragment or insert } \\
\hline & & source plasmid & $\begin{array}{l}\text { forward } \\
\text { primer }\end{array}$ & $\begin{array}{l}\text { reverse } \\
\text { primer }\end{array}$ \\
\hline pAS66 & $\begin{array}{l}\text { pFX-GA digested with XbaI } \\
\text { and BglII }\end{array}$ & $\begin{array}{l}\text { pUC57-GA } \\
\text { digested with } \\
\text { XbaI and BglII }\end{array}$ & - & - \\
\hline GAL 10-PYK & $10 \mid$ & & & \\
\hline pAS65 & $\begin{array}{l}\text { pESC-GA digested with } \\
\text { BamHI and HindIII }\end{array}$ & pUC57-GA & pARS24 & pARS25 \\
\hline $\overrightarrow{\text { GAL1 }} \mathrm{N}-$ & \begin{tabular}{|c|}
\multicolumn{2}{|c|}{$132 a a$} \\
GA CP \\
\cline { 2 - 2 }
\end{tabular} & & & \\
\hline pIC971 & $\begin{array}{l}\text { pESC-URA digested with } \\
\text { EcoRI and NotI }\end{array}$ & pAS65 & pINC402 & $\mathrm{pINC} 403$ \\
\hline \begin{tabular}{l|l|l|} 
& $132 a a$ \\
& $G A C P$
\end{tabular} & 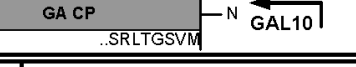 & & & \\
\hline pIC562 & $\begin{array}{l}\text { pAP409 digested with } \\
\text { Kpn2I and Mph1103I }\end{array}$ & $\begin{array}{l}\text { pTRHis2A- } \\
\text { WNV }\end{array}$ & pWNV-Kpn & pWNV-Mph \\
\hline pDA21 & $\begin{array}{l}\text { pESC-GA digested with } \\
\text { EcoRI and NotI }\end{array}$ & pAK5 & pDAR1 & pARS18 \\
\hline \multicolumn{2}{|c|}{ 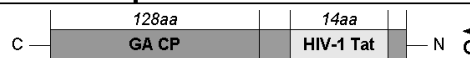 } & \multicolumn{2}{|c|}{$\vec { A L 1 0 } \longdiv { \text { GAL1 } } \mathrm { N } - \frac { \mathrm { GACP } } { \text { MVSGTLRS. } }$} & .FYA $-\mathrm{c}$ \\
\hline pIC929 & $\begin{array}{l}\text { pAS65 digested with EcoRI } \\
\text { and NotI }\end{array}$ & pAS65 & pINC354 & pINC355 \\
\hline pIC930 & $\begin{array}{l}\text { pIC929 digested with Kpn2I } \\
\text { and NotI }\end{array}$ & pIC562 & pWNV-Kpn & pINC356 \\
\hline \multirow{2}{*}{\multicolumn{2}{|c|}{\begin{tabular}{c|c|c|}
\multirow{2}{*}{$C-$} & 111aa & $129 a \mathrm{a}$ \\
\cline { 2 - 2 } & WNV DIII & GA CP \\
\end{tabular}}} & \multirow{2}{*}{$\overleftrightarrow { \text { GAL10 } } \longdiv { \text { GAL1 } } \mathrm { N }$} & $\begin{array}{l}132 a a \\
\text { GA CF }\end{array}$ & \\
\hline & & & MVSGTLRS.. &.$F Y A$ \\
\hline pIC958 & $\begin{array}{l}\text { pAS65 digested with EcoRI } \\
\text { and NotI }\end{array}$ & $\mathrm{pAC} 262$ & pINC324 & pINC325 \\
\hline & 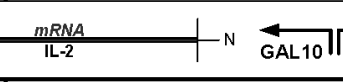 & $\overrightarrow{\mathrm{NAL1}} \mathrm{N}$ & $\begin{array}{r}132 a a \\
\mathrm{GACP} \\
\end{array}$ & $-c$ \\
\hline pIC972 & $\begin{array}{l}\text { pIC971 digested with } \\
\text { BamHI and HindIII }\end{array}$ & $\mathrm{pAC} 262$ & pINC413 & pINC414 \\
\hline$c-\overline{\text { AYF. }}$ & 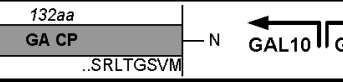 & $\overrightarrow{a L 1}$ & $\frac{m R N A}{1 \mathrm{LL}-2}$ & $c$ \\
\hline pIC984 & $\begin{array}{l}\text { pAS65 digested with EcoRI } \\
\text { and NotI }\end{array}$ & $\begin{array}{l}\text { pCEP4-CXCR4- } \\
\text { eGFP }\end{array}$ & pJAR18 & pJAR19 \\
\hline & $\frac{\text { MRNA }}{\text { eGFP }}$ & $\mathrm{N}-\longdiv { \overline { M V S G T L R S } }$ & $\frac{132 a a}{\mathrm{GA} \mathrm{CP}}$ & $-c$ \\
\hline pIC921 & $\begin{array}{l}\text { pIC971 digested with } \\
\text { BamHI and HindIII } \\
\end{array}$ & $\begin{array}{l}\text { pCEP4-CXCR4- } \\
\text { eGFP }\end{array}$ & pINC434 & pINC435 \\
\hline$c-\longdiv { \overline { A Y F } . . }$ & \begin{tabular}{l|ll}
\multicolumn{1}{|c|}{$132 a a$} & & \\
GA CP & & \\
.SRLTGSVM & &
\end{tabular} & $\rightarrow \mathrm{NL}+\mathrm{L}$ & $\frac{\text { mRNA }}{\text { EGFP }}$ & $\mathrm{C}$ \\
\hline
\end{tabular}

and inserting it in plasmid pESC-URA; other plasmids were derived from those two plasmids.

Plasmid pIC562 was constructed to "stick" the West-Nile virus envelope protein domain III (WNV-EDIII) sequence to the C-terminus of Acinetobacter phage AP205 coat protein. The WNV-DIII sequence was cloned from pTRHis2A-WNV plasmid (Martina et al., 2008), inserted in vector plasmid pAP409 (Tissot et al., 2010) and expressed in E. coli JM109 cells.

In the first step, to obtain mosaic virus-like particles, the construction pIC929 was created in which GA CP sequences were inserted under control of both promoters (Gal1 and Gal10). GA CP under control of Gal10 promoter was C-terminally fused with the WNV-EDIII sequence, which was cloned out from construction pIC562. In the case of construction pDA21, pESC-GA plasmid (Freivalds et al., 2008) was modified by inserting, under control of the Gal10 promoter, the GA CP gene that was previously N-terminally prolonged with the HIV-Tat (48-60) sequence (from construction pAK5 for expression in E. coli system). Therefore, this construct was made with $E$. coli-specific codons.

For in vivo packaging, four constructions were made - two with the interleukin 2 (IL2) sequence cloned from plasmid pAC262 (Avots et al., 1990) and two with the eGFP sequence cloned from plasmid pCEP4-CXCR4-eGFP (Strods et al., 2010). Each of the genes was cloned in GA CP containing pESC-URA plasmid, under control of either under Gal1 or Gal10 promoter.

Transformation and protein production. S. cerevisiae strain AH22 competent yeast cells were transformed with 
appropriate plasmids (pFX or pAS66) and cultivated for GA CP expression as described by Freivalds et al., 2008.

S. cerevisiae strain YPH499 competent cells were transformed with appropriate pESC-URA plasmids by using standard lithium acetate/polyethylene glycol procedure (by using Yeast Transformation Kit (Sigma)) as described by Gietz et al. (1992). Transformants were selected on uracilfree agarised synthetic dextrose minimal medium (SDU') according to the manufacturer's protocol. Analytic expression was performed for clone selection. For cell multiplication, $5 \mathrm{~mL} \mathrm{SDU}$ medium and incubation in $30{ }^{\circ} \mathrm{C}$ for $24 \mathrm{~h}$ were used. For expression, $1 \mathrm{~mL}$ inoculum and $5 \mathrm{~mL}$ uracil-free synthetic galactose minimal medium ( $\mathrm{SGU}^{-}$) and incubation in $30{ }^{\circ} \mathrm{C}, 200 \mathrm{rpm}$ for 24 hours were used. Protein content in cells was determined with Western blotting. Selected clones were cultivated for preparative protein expression. $5 \mathrm{~mL}$ of inoculum were incubated in $100 \mathrm{~mL} \mathrm{SDU}^{-}$in $30{ }^{\circ} \mathrm{C}, 200 \mathrm{rpm}$ for 24 hours; the cells were collected by centrifugation (3000 rpm, $5 \mathrm{~min}$ ) and resuspended in 200 $\mathrm{mL} \mathrm{SGU}{ }^{-}$and cultivated for $48 \mathrm{~h}$. Preparative cultivation was conducted in $1 \mathrm{~L}$ flasks.

Purification of VLPs. For purification, 3-8 grams of yeast cells were resuspended in $10 \mathrm{~mL}$ of buffer solution $\mathrm{B}(20$ $\mathrm{mM}$ Tris- $\mathrm{HCl}, 5 \mathrm{mM}$ EDTA, $0.65 \mathrm{M} \mathrm{NaCl}, \mathrm{pH} 7.8$ ) supplemented with $0.03 \mathrm{mM}$ PMSF. For cell disruption, suspension was subjected to the French press (three strokes, 20000 psi), then stirred with $5 \mathrm{~mL}$ glass beads (Sigma) (30 sec of stirring and $1 \mathrm{~min}$ of cooling on ice, 15 cycles) and, finally, sonicated with $22 \mathrm{kHz}$ ultrasound (15 sec of sonication and $1 \mathrm{~min}$ of cooling on ice, 5 cycles). Insoluble cell debris was avoided by centrifugation (30 min, 12000 $\mathrm{rpm}$ ). The pellet wash (with $5 \mathrm{ml}$ of buffer solution B) was added to the previous supernatant for concentration by dialysis against buffer solution B : glycerol (1:1) for 24 hours. Concentrated material was loaded onto a Sepharose CL-4B gelfiltration column $(2 \times 63 \mathrm{~cm})$ with buffer solution B flow rate approximately $2 \mathrm{~mL} \cdot \mathrm{h}^{-1}$.

Capsids were pooled and concentrated by addition of solid ammonium sulphate to $60 \%$ of saturation and incubation overnight at $-18{ }^{\circ} \mathrm{C}$. After centrifugation (15 min, 10000 $\mathrm{rpm})$, the sediment was solubilised into $1 \mathrm{~mL}$ buffer $\mathrm{B}$ and dialysed against buffer TEN (20 mM Tris- $\mathrm{HCl}, 5 \mathrm{mM}$ EDTA, 0.15 M NaCl, pH7.8) with a lower amount of sodium chloride. Contaminant nucleic acids were removed by passing through a short DEAE-Sephadex A50 ion-exchange column according to Rūmnieks et al., 2008.

Final purification of VLPs was performed by sucrose density gradient ultracentrifugation on an ultracentrifuge Optima L-100XP with SW32Ti rotor at 20500 rpm 13 hours. Centrifuge tubes were filled with layers of descending concentrations of sucrose solutions, starting with $36 \%$ on bottom till $5 \%$ on top. After fractionation and analysis, capsids were collected and dialysed against buffer solution B : glycerol $(1: 1)$ and stored.
Analysis of incapsided nucleic acids. Nucleic acids from $0.2 \mathrm{mg}$ of purified capsids were extracted using phenol as described by Rūmnieks et al., 2008. Synthesis of the first strand cDNA was conducted using the First strand cDNA synthesis kit (Fermentas) according to the manufacturer's protocol; 1/10 of extracted RNA was used as a template for each of the corresponding primers - random hexamers, oligo $(\mathrm{dT})_{18}$, forward primer against GA $\mathrm{CP}$, and forward primer against IL-2 or against eGFP gene sequence. For second strand cDNA synthesis by PCR reaction, both forward and reverse primers were added to $2 \mu \mathrm{L}$ of each mixture and products were analysed in agarose gel electrophoresis (Fig. 5).

Polyclonal antibodies against West-Nile virus E protein DIII sequence. Plasmid pIC562 was expressed in E. coli JM109. After ultrasonification of cells in lysis buffer (10 mM Tris-HCl, 5 mM EDTA, 0.03 mM PMSF, pH7.8), soluble proteins were removed by centrifugation at $12000 \mathrm{rpm}$ for 45 min. Fusion protein P562 (AP205 CP - WNV EDIII fragment) was extracted from the pellet with $7 \mathrm{M}$ urea in water and placed on a column with DEAE-cellulose, pre-equilibrated with $0.02 \mathrm{M}$ Tris-HCl, pH8.6. Protein P562 did not absorb and was collected by washing out with equilibration buffer and sedimented with equal volume of saturated ammonium sulphate. For immunisation, a solution of P562 in 7 M urea was prepared.

The immunisation of five Balb/c mice was conducted by simultaneous peritoneal and subcutaneous injections of $25 \mu \mathrm{g}$ of purified virus-like particles in total volume $200 \mathrm{~m} \mu \mathrm{L}$, supplemented with complete Freund's adjuvant (Sigma) in equal amounts. Two re-immunisations were conducted after 14 and 28 days in the same manner, but by using incomplete Freund's adjuvant (Sigma) instead of complete Freund's adjuvant. Mice were bled after 42 days and the collected blood was incubated for $30 \mathrm{~min}$ at $+37^{\circ} \mathrm{C}$ and for $20 \mathrm{~min}$ at $+4{ }^{\circ} \mathrm{C}$. After centrifugation serum was collected and mixed with glycerol $(1: 1)$ for storage in $-20{ }^{\circ} \mathrm{C}$.

Permission from the Food and Veterinary Service was obtained.

Polyacrylamide gel elecrophoresis and Western blotting. PAGE was performed in Tris-glycine buffer with $21 \%$ resolution gel and $6 \%$ stacking gel, and bands were silver-stained according to standard procedure. Western-blots were made with rabbit polyclonal anti - GA CP VLPs (as an antigen for antibody production, GA CP VLPs produced in E. coli (from construction pGA-355-24) and protein A HR peroxidase conjugate (Sigma)) were used.

\section{RESULTS}

A set of plasmids was created to construct GA CP-based mosaic particles and to develop in vivo packaging of VLPs with the desired mRNAs (Table 1). The advantage of the used commercial expression system pESC-URA is it universality, which allows to manufacture plasmids in $E$. coli 
OLIGONUCLEOTIDE PRIMERS USED FOR THE CONSTRUCTION OF PLASMIDS AND RT-PCR

\begin{tabular}{ll}
\hline Oligonucleotide & Nucleotide sequence (5' to 3') \\
pARS24 & TTGGATCCACAATGGCTACTTTGAGATCATTTGTTTTGGT \\
pARS25 & TTTAAGCTTAAGCATAGAAACCAGATTGAGAAGAAATA \\
pINC402 & CCGAATTCACAATGGCTACTTTGAGATCA \\
pINC403 & TAGCGGCCGCTTAAGCATAGAAACCAGATTGAGA \\
pDAR1 & ATGAATTCGGATCCCCATGGGATATGGTCGTAAGAAAC \\
pARS18 & TAGCGGCCGCAAGCTTACGCGTAGAAGCCACTCTGT \\
pINC354 & TCGAATTCATGGCCCCTACTTCAAGTTCTAC \\
pINC355 & ATGCGGCCGCTTAAGTCAGTGTTGAGATGATGC \\
pWNV-Kpn & CATCCGGACAGTTGAAGGGAACAAC \\
pWNV-Mph & GTATGCATTATTTGCCAATGCTGCTTCC \\
pINC356 & ATGCGGCCGCTTATTTGCCAATGCTGCTTCC \\
pINC324 & TCGAATTCATGGCCCCTACTTCAAGTTCTAC \\
pINC325 & ATGCGGCCGCTTAAGTCAGTGTTGAGATGATGC \\
pINC413 & TAGGATCCACAATGGCCCCTACTTCAAGTTCTAC \\
pINC414 & TACAAGCTTAAGTCAGTGTTGAGATGATGC \\
pINC434 & TAGGATCCATGGTGAGCAAGGGCGAGGA \\
pINC435 & TCTAAGCTTACTTGTACAGCTCGTCCATGCC \\
pJAR18 & TCGAATTCCATGGTGAGCAAGGGCGAGGA \\
pJAR19 & GAGCGGCCGCAAGCTTACTTGTACAGCTCGTCCAT \\
p1.561 & TGCCATGGCAACTTTACGCAGTTTCG \\
p1.562 & TGAAGCTTACGCGTAGAAGCCACTCTG \\
&
\end{tabular}

Restriction endonuclease sites are underlined; initiation and termination codons are in bold

as a host and therefore to involve vectors for expression of VLPs in bacteria. Table 2 represents sequences of oligonucleotide primers used to create constructs for VLP production. To check the effect of codon changes made in the $\mathrm{CP}$ coding part of the plasmid on the production of GA CP VLP, we compared yields of capsids with previously exploited construction $\mathrm{pFX}-\mathrm{GA}$ and the new construct pAS66 (Table 1).

Previous work had shown that, comparing the used $S$. cerevisiae systems AH22/pFX-GA and YPH499/pESC-URA, the first of them, which was formaldehyde inducible, gave slightly higher yield of particles (Freivalds et al., 2008). Hence just this system was chosen to compare yield of the product coded by the original $E$. coli-specific sequence and our ,improved” plasmid pAS66. Using pAS66 we obtained stably higher yield of particles, the process became more repeatable, and production reached two milligrams per one gram of yeast cells. Therefore, in our further constructs for the system of interest YPH499/pESC-URA (uracil auxotrophy), new CP coding sequences were exploited, excepting construct pDA21 with E. coli origin codons (Table 3). We focused on two-promoter system possibilities, rather than on the yield of products, as it is well known that $S$. cerevisiae prefers glucose as a carbon source and its growth rate is much higher in glucose than in galactose-containing media, which is necessary for activation of both promoters in pESC-URA. In all cases investigated till now, yield of purified capsids was at least $1 \mathrm{mg}$ per gram of yeast cells.
Table 3

CHARACTERISTICS OF CONSTRUCTIONS EXPRESSED IN THE SYSTEM Saccharomyces cerevisiae YPH499/PESC-URA FOR PRODUCTION OF VLPS

\begin{tabular}{l|l|l|l}
\hline \multicolumn{1}{c}{ Purpose } & $\begin{array}{c}\text { Construction, } \\
\text { number }\end{array}$ & Promoters & \multicolumn{1}{c}{ Genes } \\
\hline VLPs yields & pAS65 & GAL1 & GA CP \\
\hline & pIC971 & GAL10 & GA CP \\
\hline mosaic particles & pDA21* & GAL1 & GA CP \\
& pIC930 & GAL1 & GIV-Tat(48-60) + GA CP \\
\hline packaging in vivo & pIC958 & GAL1 & GA CP \\
of mRNAs & GAL10 & IL2 \\
\cline { 2 - 5 } & pIC972 & GAL1 & IL2 \\
\cline { 2 - 5 } & GAL10 & GA CP \\
\cline { 2 - 5 } & pIC921 & GAL1 & GA CP \\
& pIC984 & GAL1 & GFP \\
& & GAL10 & GA CP
\end{tabular}

* both GA CP coding sequences are E. coli origin

Protein modifications can occur in yeast - particularly phosphorylation, which can affect up to $30 \%$ of the proteome (Ptacek et al., 2005) and usually affects serine residues (Cobitz et al., 1989). Phosphorylation of GA CP in our cases was not observed, which is surprising, as each 129-aminoacid-long GA CP molecule contains 14 serines. In the cases of VLPs produced from plasmids pAS65, 

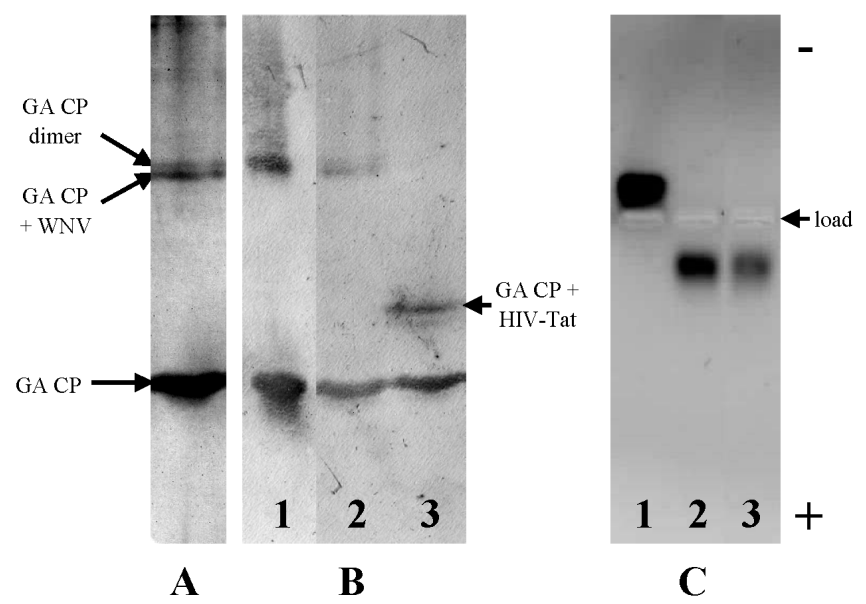

Fig. 2. Analysis of VLPs by PAAG (A and B) and agarose gel (C) electrophoresis: A - silver staining of purified construction IC930 VLPs; B Western blotting of constructions 355-24 (1), IC930 (2) and DA21 (3); C purified VLPs from constructions 355-24 (1), IC930 (2) and IC972 (3).

pAS66, pIC930 and pIC958, two tests (proQ Diamond phosphoprotein gel staining of CP in PAAG and incubation with PME with subsequent electrophoresis of capsids in native agarose gel) did not show phosphorylation of GA (data not shown). It is interesting that electrophoretic mobility of GA CP-formed capsids from E. coli (355-24) and from yeast (pIC930 and pIC972) was quite different in native agarose gels compared with that of coat protein in PAAG (Fig. 2C).

We attempted to obtain mosaic particles consisting of native $\mathrm{CP}$ and of $\mathrm{CP}$ fused with foreign sequences. Two such constructs, pDA21 and pIC930, were successfully expressed (Table 3). In both cases, N- terminal (DA21) and C-terminal (IC930) (Fig. 2A) fusions were involved (Fig. 3A). Two products were obtained: particles with HIV-1 Tat sequence 48-60 (Vivčs et al., 1997) and with West Nile EDIII sequence (Martina et al., 2008) (Fig. 4A). Western-blot analy-
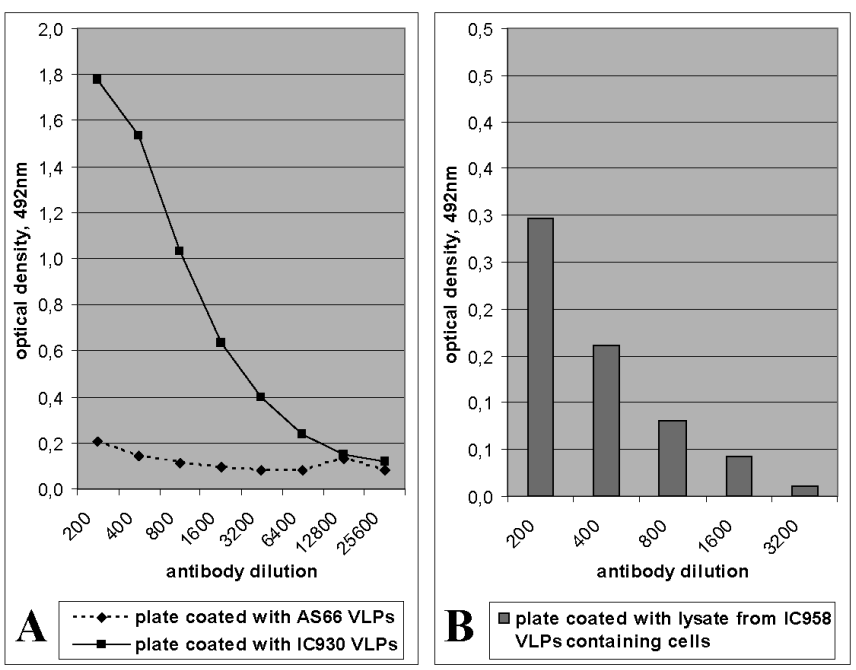

Fig. 3. ELISA immunodetection: A - AS66 and IC930 VLPs with murine polyclonal 562 antibodies against WNV EDIII; B - lysates from cells with expressed construction pIC958 VLPs with anti-interleukin-2 antibodies; displayed values are after subtraction of control (e.g., lysate from untransformed YPH499 cells).
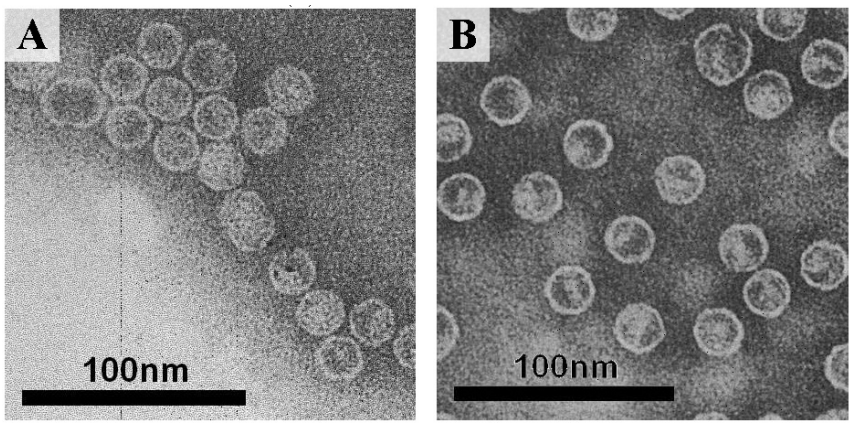

Fig. 4. Electronmicroscopy of mosaic VLPs - construction IC930 (A) and of VLPs with packaged IL-2 mRNA - construction IC972 (B).

sis gave convincing evidence of mosaic particles, as besides monomers and dimers of GA CP, also bands of fused prolonged coat protein (Fig. 2B) were evident. Construct expression in pESC-URA vector allowed to obtain the HIV-1 Tat 48-60 sequence for study as a cell membrane-transducing address. Similar particles obtained by expression in $E$. coli were not formed (data not shown). However, use of another similar construct, in which GA CP was N-terminally fused with the vMIPII fragment (not shown) resulted in capsids in E. coli, but not in yeast. Therefore, the use of both bacterial and yeast expression systems allow us to broaden the set of mosaic virus like particles.

While considering that in the future we need packaged GFP mRNA as a reporter for delivery experiments, two sorts of mRNAs were packaged under control of both promoters that resulted in four constructions: two for packaging of green fluorescent protein (GFP) mRNA (constructions IC984 and IC921) and two for packaging of IL2 mRNA (constructions IC958 un IC972). After accurate purification of produced VLPs, including sucrose density gradient ultracentrifugation to avoid even traces of "stuck" nucleic acids, capsids were treated with phenol and internal nucleic acid was collected. Random hexamer primers indicate the total RNA pool (Fig. 5, lines 1). Primer oligo(dT) allows to visualise all mRNAs, as they have poly(A) tracts (Fig. 5, lines $2)$. The utilised experimental conditions allowed us to compare amounts of mRNA by comparing material in specific PCR product bands. Lines 3 (Fig. 5) showed negligible amounts of GA coat protein mRNA, but cogent bands corresponding to GFP and IL2 coding sequences (Fig. 5, lines $4 \mathrm{a}-4 \mathrm{~d})$ demonstrated packaging of desired mRNAs in vivo into particles.

\section{DISCUSSION}

Yeast provides a source of eukaryotic 5'-capped and 3'-poly(A)-tailed mRNAs, which is attractive considering our goal to use GA VLPs as RNA packaging and delivery tools in mammalian cells. Also, the absence of bacterial endotoxins in yeast preparations is a good reason to choose this system for in vivo packaging studies. In previous studies, genes of interest for packaging were inserted under control of the Gal10 promoter (Legendre and Fastrez, 2005; Rūmnieks et al., 2008). We also used this method, but with 

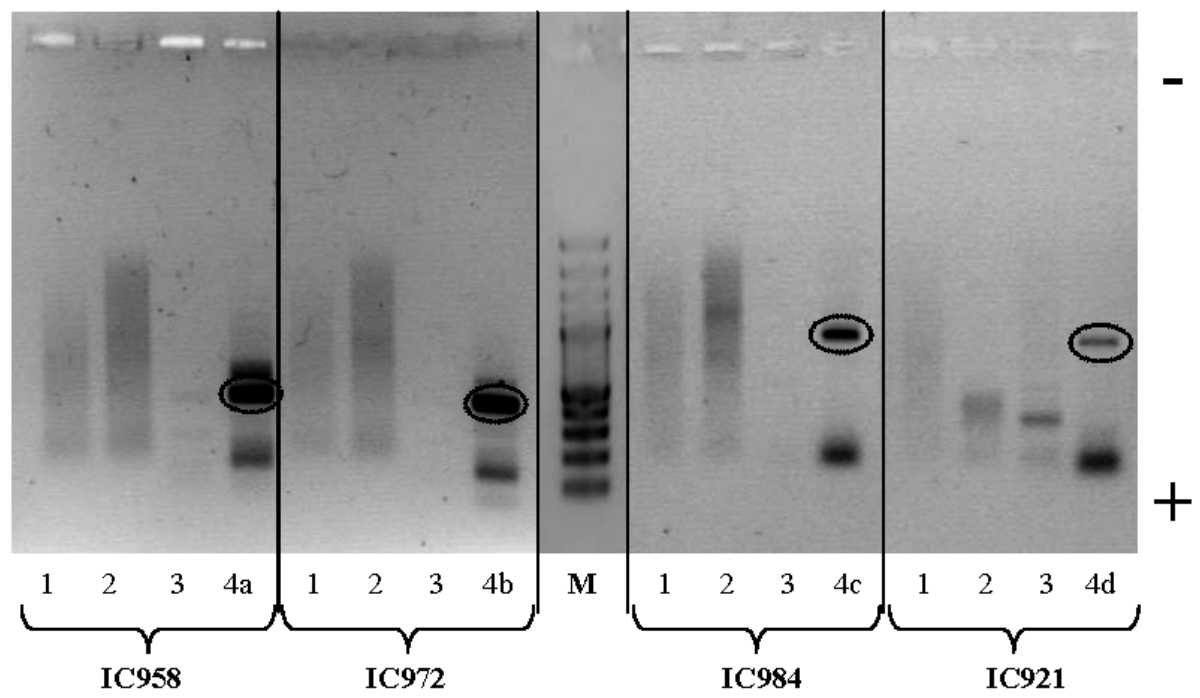

Fig. 5. Analysis of VLPs inner RNA contents by agarose gel electrophoresis. RT-PCR products for constructions IC958, IC972, IC984 and IC921 were compared with a set of different primers: 1 - random hexamer primers; 2 - oligo(dT) 18 primers; 3 - GA CP primers $(\mathrm{p} 1.561+\mathrm{p} 1.562) ; 4 \mathrm{a}-$ construction IC958 with IL2 specific primers pINC324 and pINC325; 4b - construction IC972 with IL2 specific primers pINC413 and pINC414; $4 \mathrm{c}$ - construction IC984 with eGFP specific primers pJAR18 and pJAR19; 4d - construction IC921 with eGFP specific primers pINC434 and pINC435. DNA Ladder 100bp (Fermentas) was used as a marker (M). Ellipses frame bands with densities corresponding to amounts of IL2 mRNA ( $4 \mathrm{a}$ and $4 \mathrm{~b}$ ) and eGFP mRNA (4c and $4 d)$. substituted constructions (Table 1, constructions pIC972 and pIC984). It was previously shown that packaging of heterologous mRNAs into GA CP particles occurred independently of the presence or absence of the specific stem-loop operator sequence (Rūmnieks et al., 2008). This is consistent with the rather low specificity of GA coat protein to structure of the operator (Gott et al., 1991) and explains the encapsidation of different RNAs. Even in the case of MS2 coat protein, which is well known as to form stable replicative complex I (coat protein + operator sequence of RNA), encapsidation efficiency and specificity to a greater extent affects the concentration of mRNA rather than its source (Picket and Peabody, 1993). Therefore, we were interested in examining the yield of GA CP particles and their RNA packaging capacity and specificity by changing promoters for expression of structural coat protein and corresponding mRNA.

Interleukin-2 is a secreted cytokine that is important for Tand B- lymphocyte proliferation. IL2 is produced by T-cells in response to antigenic and mitogenic stimulation and is required for T-cell proliferation and other activities crucial to regulation of the immune response. IL2 can stimulate B-cells, monocytes, lymphokine-activated killer cells and natural killer cells. Despite of unclear, even negative or contradictory results, IL2 still remains a promising therapeutic tool for melanoma and glioma treatment (Fenstermaker and Ciesielski, 2004; Albertini et al., 2008). In VLPs packaged IL2, mRNA is foreseen for local treatment, when VLPs will be able to deliver it into cells. Beside the liposomal intracellular delivery system (Pakunlu et al., 2006), RNA phage MS2 coat protein formed particles were demonstrated as candidates for delivery of mRNAs into eukaryotic cells (Legendre and Fastrez, 2005; Sun et al., 2011). These studies suggest that we are on the path to creating a drug delivery vehicle based on GA coat protein capsids.

\section{ACKNOWLEDGEMENTS}

We wish to thank Prof. Pauls Pumpēns for the idea to use optimised codons for coat protein expression in yeast cells.
We thank also Dr. Velta Ose-Klinklāva for electron microscopy imaging, and Dr. Dace Skrastina for performing mouse immunisation procedures.

We are very grateful to Prof. Kęstutis Sasnauskas and Dr. Aistè Bulavaite from the Institute of Biotechnology, Vilnius University, for the possibility to obtain experience in work with yeasts.

This work was supported by Latvian National Research Programme No. 4 "BIOMEDICINE" project 2010-7/7.2.

\section{REFERENCES}

Albertini, M. R., Hank, J. A., Schalch, H., Kostlevy, J., Cassaday, R., Gan, J., Kim, K., Clements, B., Gillies, S. D., Sondel, P. M. (2008). Phase II trial of hu14.18-IL2 (EMD 273063) for patients with metastatic melanoma. $J$. Clin. Oncol., 26, May 20 Supplement, abstr. 9039.

Chen, H., Lü, J. H., Liang, W. Q., Huang, Y. H., Zhang, W. J.. Zhang, D. B. (2004). Purification of the recombinant hepatitis B virus core antigen ( $\mathrm{rHBcAg}$ ) produced in the yeast Saccharomyces cerevisiae and comparative observation of its particles by transmission electron microscopy (TEM) and atomic force microscopy (AFM). Micron, 35 (5), 311-318.

Cobitz, A. R., Yim, E. H., Brown, W. R., Perou, C. M., Tamanoi, F. (1989). Phosphorylation of RAS1 and RAS2 proteins in Saccharomyces cerevisiae. Proc. Nat. Acad. Sci. USA, 86 (3), 858-862.

Fenstermaker, R. A., Ciesielski, M. J. (2004). Immunotherapeutic strategies for malignant glioma. Cancer Control, 11 (3), 181-191.

Freivalds, J., Dislers, A., Ose, V., Skrastina, D., Cielens, I., Pumpens, P., Sasnauskas, K., Kazaks, A. (2006). Assembly of bacteriophage Qbeta virus-like particles in yeast Saccharomyces cerevisiae and Pichia pastoris. J. Biotechnol., 123 (3), 297-303.

Freivalds, J., Rūmnieks, J., Ose, V., Renhofa, R., Kazāks, A. (2008). Highlevel expression and purification of bacteriophage GA virus-like particles from yeast Saccharomyces cerevisiae and Pichia pastoris. Acta Univ. Latv., 745, Biology, 75-85.

Freivalds, J., Dislers, A., Ose, V., Pumpens, P., Tars, K., Kazaks, A. (2011). High efficient production of phosphorylated hepatitis B core particles in yeast Pichia pastoris. Protein Expr. Purif., 75, 218-224.

Gietz, D., Jean, A. S., Woods, R. A., Schiestl, R. H. (1992). Improved method for high efficiency transformation of intact yeast cells. Nucl. Acids Res., 20 (6), 1425.

Gott, J. M., Wilhelm, L. J., Uhlenbeck, O. C. (1991). RNA binding properties of the coat protein from bacteriophage GA. Nucl. Acids Res., 19 (23), 6499-6503. 
Juozapaitis, M., Slibinskas, R., Staniulis, J., Sakaguchi, T., Sasnauskas, K. (2005). Generation of Sendai virus nucleocapsid-like particles in yeast. $\mathrm{Vi}$ rus Res., 108 (1-2), 221-224.

Klump, H. H., Maeder, D. L. (1991). The thermodynamic basis of the genetic code. Pure Appl. Chem., 63 (10), 1357-1366.

Legendre, D., Fastrez, J. (2005). Production in Saccharomyces cerevisiae of MS2 virus-like particles packaging functional heterologous mRNAs. $J$. Biotechnol., 117 (2), 183-194.

Mach, H., Volkin, D. B., Troutman, R. D., Wang, B., Luo, Z., Jansen, K. U., Shi, L. (2006). Disassembly and reassembly of yeast-derived recombinant human papilloma virus-like particles (HPV VLPs). J. Pharmaceut. Sci., 95 (10), 2195-2206

Martina, B. E., Koraka, P., van den Doel, P., van Amerongen, G., Rimmelzwaan, G. F., Osterhaus, A. D. (2008). Immunization with West Nile virus envelope domain III protects mice against lethal infection with homologous and heterologous virus. Vaccine, 26 (2), 153-157.

Pakunlu, R. I., Wang, Y., Saad, M., Khandare, J. J., Starovoytov, V., Minko, T. (2006). In vitro and in vivo intracellular liposomal delivery of antisense oligonucleotides and anticancer drug. J. Contr. Release, 114 (2), 153-162.

Picket, G. G., Peabody, D. S. (1993). Encapsidation of heterologous RNAs by bacteriophage MS2 coat protein. Nucleic Acids Res., 21 (19), 4621-4626.

Ptacek, J., Devgan, G., Michaud, G., Zhu, H., Zhu, X., Fasolo, J., Guo, H., Jona, G., Breitkreutz, A., Sopko, R., McCartney, R. R., Schmidt, M. C., Rachidi, N., Lee S. J., Mah, A. S., Meng, L., Stark, M. J. R., Stern, D. F., De Virgilio, C., Tyers, M., Andrews, B., Gerstein, M., Schweitzer, B., Predki, P.F., Snyder, M. (2005). Global analysis of protein phosphorylation in yeast. Nature Letters, 438, 679-684.

Rūmnieks, J., Freivalds, J., Cielēns, I., Renhofa, R. (2008). Specificity of packaging mRNAs in bacteriophage GA virus-like particles in yeast Saccharomyces cerevisiae. Acta Univ. Latv., 745, Biology, 145-154.
Strausberg, R. L., Strausberg, S. L. (2001). Overview of protein expression in Saccharomyces cerevisiae. Curr. Protocols Protein Sci. 5.6.1-5.6.7.

Sasnauskas, K., Bulavaite, A., Hale, A., Jin, L., Knowles, W. A., Gedvilaite, A., Dargeviciūte, A., Bartkeviciūte, D., Zvirbliene, A., Staniulis, J., Brown, D. W., Ulrich, R. (2002). Generation of recombinant virus-like particles of human and non-human polyomaviruses in yeast Saccharomyces cerevisiae. Intervirology, 45 (4-6), 308-317.

Strods, A., Petrovska, R., Jackeviča, L., Renhofa R. (2010). Cloning and expression of chemokine receptor CXCR4 in eukaryotic cells CHO, HEK293 and BHK21. Proc. Latv. Acad. Sci. Section B, 64 (3/4), 98-105.

Sun, S., Li, W., Sun, Y., Pan, Y., Li, J. (2011). A new RNA vaccine platform based on MS2 virus-like particles produced in Saccharomyces cerevisiae. Biochem. Biophys. Res. Comm., 407 (1), 124-128.

Tars, T., Bundule, M., Fridborg, K., Liljas, L. (1997). The crystal structure of bacteriophage GA and a comparison of bacteriophages belonging to the major groups of Escherichia coli leviviruses. J. Mol. Biol., 271, 759-773.

Tissot, A. C., Renhofa, R., Schmitz, N., Cielens, I., Meijerink, E., Ose, V., Jennings, G. T., Saudan, P., Pumpens, P., Bachmann, M. F. (2010). Versatile virus-like particle carrier for epitope based vaccines. PLoS One, 5 (3), e9809.

Tsunetsugu-Yokota, Y., Morikawa, Y., Isogai, M., Kawana-Tachikawa, A., Odawara, T., Nakamura, T., Grassi, F., Autran, B., Iwamoto, A. (2003). Yeast-derived human immunodeficiency virus type 1 p55(gag) virus-like particles activate dendritic cells (DCs) and induce perforin expression in Gag-specific CD8(+) T cells by cross-presentation of DCs. J. Virol., 77 (19), 10250-10259.

Vivčs, E., Brodin, P., Lebleu, B. (1997). A truncated HIV-1 Tat protein basic domain rapidly translocates through the plasma membrane and accumulates in the cell nucleus. J. Biol. Chem., 272 (25), 16010-16017.

Авотс А., Бундулис Я., Осе В., Романчикова Н., Скривелис В., Янкевиц Е., Циманис А., Грен Е. (1990). [The expression of the human interleukin-2 gene in Escherichia coli bacteria]. Докл. Акад. Наук CCCP, 315 (4), 994-996 (in Russian).

Received 3 April 2012

\section{GA APVALKA PROTEĪNA ATVASINĀTO MOZAIKĀLO VĪRUSIEM LĪDZĪGO DAḶIṆU EKSPRESIJA Saccharomyces cerevisiae UN mRNS in vivo IEPAKOŠANA DAL̦IṆĀS}

Mūsu iepriekšējie pētījumi parādījuši, ka lielākais RNS bakteriofāga GA apvalka proteīna veidoto vīrusiem līdzīgo daḷiņu (VLD) ieguvums ir ekspresējot tās raugos Pichia pastoris; savukārt, izmantojot Saccharomyces cerevisiae ekspresijas sistēmu, kapsīdu ieguvums ir daudz mazāks. Divi galvenie mērḳi turpmākajām studijām raugos Saccharomyces cerevisiae bija paaugstināt GA apvalka proteīna veidoto VLD ieguvumu, izmantojot konstrukcijas ar optimizētu nukleotīdu tripletu sekvencēm, un izpētìt iespējas, ko varētu sniegt divu promoteru Gal1/Gal10 saturošs ekspresijas vektors pESC-URA vēlamo mozaīkveida VLD iegūšanai un mRNS iepakošanai VLD in vivo. 